\title{
PERBEDAAN DISTRIBUSI KEKERASAN METODE MINIMUM QUANTITY LUBRICATION (MQL) DAN METODE WET MACHINING PADA MATERIAL Al-Zn
}

\author{
Wildan Shofiyandi ${ }^{1}$, Heri Yudiono ${ }^{2}$ \\ Jurusan Teknik Mesin FT Unnes ${ }^{1}$, Jurusan Teknik Mesin FT Unnes ${ }^{2}$ \\ Email : des007.co@gmail.com
}

\begin{abstract}
This study aims to determine the influence of three different coolant delivery methods, namely dry machining, Minimum Quantity Lubrication (MQL), and wet machining. This is a quantitative research with the use of experimental methods. Data were collected through observation. Data analysis techniques being used was descriptive statistics. In MQL methods, the use of coolant is minimized by mixing it with high-pressurized air. It is shown from the obtained data that the use of MQL methods is not as good as the wet machining. The hardness distribution of wet machining method is lower than the MQL. This was observed from the machining chips of the two methods. The chips from the MQL method were darker than the wet machining method. This finding showed that the heat generated from the MQL was higher than that of wet machining. The Al and $\mathrm{Zn}$ bonds in the MQL method is considered to be denser.
\end{abstract}

Keywords: MQL, wet machining, heat, hardness distribution

\begin{abstract}
ABSTRAK
Penelitian ini bertujuan untuk mengetahui seberapa besar pengaruh penggunaan metode pemberian coolant yang berbeda, 3 metode yang digunakan adalah metode dry machining, Minimum Quantity Lubrication (MQL), dan wet machining. Penelitian ini termasuk jenis penelitian kuantitatif dan menggunakan metode eksperimen. Untuk teknik pengumpulan data menggunakan metode observasi dan teknik analisis data menggunakan teknik analisis statistik deskriptif. Metode MQL merupakan metode yang digunakan untuk meminimalisir penggunaan coolant dengan mencampurkannya dengan udara bertekanan tinggi. Data yang didapat menunjukkan bahwa penggunaan metode MQL belum sebaik penggunaan metode wet machining. Distribusi kekerasan metode wet machining lebih rendah daripada MQL. Hal tersebut dapat terlihat dari geram yang dihasilkan oleh kedua penggunaan metode tersebut, geram yang dihasilkan dari metode MQL lebih gelap daripada metode wet machining. Hal tersebut menunjukkan bahwa, panas yang dihasilkan dari metode MQL lebih tinggi daripada panas yang dihasilkan dari metode wet machining panas tersebut mempengaruhi ikatan $\mathrm{Al}$ dan Zn pada metode MQL menjadi lebih rapat.
\end{abstract}

Kata Kunci: MQL, wet machining, panas, distribusi kekerasan

\section{PENDAHULUAN}

Penggunaan mesin Computer Numerical Control (CNC) merupakan salah satu otomasi industri. CNC adalah mesin yang dilengkapi dengan komputer yang mampu menyimpan dan memproses sejumlah angka dan huruf (data) yang selanjutnya menjadi data lintasan, dan data perintah. Mesin frais merupakan salah satu mesin yang dapat diberikan system otomasi. Penggunaan mesin frais sangat luas, seperti: pembuatan molding, proses finishing, pembuatan roda gigi.

Proses pemesinan tidak dapat dipisahkan dari penggunaan cairan pendingin atau coolant. Metode pemesinan dengan menggunakan cairan pendingin ini biasa disebut wet machining. Metode ini menggunakan cairan pendingin yang dialirkan menuju benda kerja yang berfungsi untuk menghilakan geram dan juga berfungsi untuk mendinginkan suhu dari benda kerja dan pisau yang saling bergesekan. Cairan 
pendingin yang telah digunakan tadi akan menuju ke tempat penampungan yang nantinya akan digunakan kembali pada proses pemesinan yang akan datang. Penggunaan cairan pendingin yang berulang akan berdampak pada kualitas benda kerja. Cairan pendingin yang digunakan berulang-ulang akan mengalami penurunan performa. Tak terkecuali dampak yang ditimbulkan pada lingkungan, penggunaan cairan pendingin yang berlebihan dan dibuang sembarangan akan merugikan lingkungan sekitar industri berada. Oleh karena itu, penghematan penggunaan cairan pendingin harus dilakukan.

Diperkenalkannya ISO 140001 yaitu, undang-undang yang mengatur tentang lingkungan hidup, diundang-undang ini setiap perusahaan dianjurkan untuk mengurangi penggunaan coolant dalam proses pemesinan. Diperlukan metode dengan menggunakan coolant yang seminimal mungkin dengan menggunakan minyak nabati atau bahan yang lebih ramah lingkungan. Salah satu metode yang digunakan adalah MQL (Minimum Quantity Lubrication). MQL sendiri dapat didefinisikan sebagai media suplai pelumasan dalam bentuk aerosol (Klocke, 2011).

MQL merupakan suatu teknologi dalam proses pemesinan yang menggunakan gas bertekanan yang berfungsi untuk mengurangi penggunaan coolant dalam suatu proses pemesinan. Salah satu jenis gas yang dapat digunakan adalah udara dengan suhu kamar. MQL sendiri merupakan metode yang ekonomis dan ramah lingkungan. Penambahan udara ini berfungsi agar coolant yang dihasilkan membentuk aerosol yang nantinya akan diseprotkan pada ujung mata pisau. Terdapat dua metode suplai coolant pada MQL, yaitu External MQL supply dan Internal MQL Supply.

Penggunaan metode MQL dengan pemberian cairan pendingin yang minimum tetapi memberikan fungsi pendingin dan pelumasan yang baik. Pemberian cairan pendingin secara manual dan konstan terhadap parameter pemesinan. Teknik ini akan mengurangi gesekan antara pahat dan benda kerja sehingga mengurangi laju kenaikan temperatur pahat dan akhirnya akan menaikan umur pahat (Budi Basuki, 2014). Penggunaan fluida lubrikasi sangat kecil yaitu kurang dari $500 \mathrm{ml} /$ jam sehingga benda kerja, pahat, mesin, tatal, dan lingkungannya relatif kering (Klockle, 2011).

Penggunaan metode MQL ini sangat berpengaruh pada kualitas dari cairan pendingin yang digunakan. Cairan yang digunakan pada proses MQL hanya digunakan sekali dan tidak digunakan lagi, karena ketika cairan pendingin digunakan kembali cairan ini juga akan terkontaminasi oleh pelumas dari mesin sehingga kualitas cairan pendingin itu akan turun. Perubahan kualitas dari cairan pendingin ini akan berdampak pada kualitas hasil pekerjaan yang menurun pula. Selain itu, penggunaan MQL tentunya akan menurunkan atau menghemat penggunaan cairan pendingin yang digunakan. Penurunan penggunaan cairan pendingin ini tentunya akan berdampak pada pengurangan pencemaran lingkungan akibat limbah yang dhasilkan oleh cairan pendingin tersebut.

Pada metode MQL, cairan yang digunakan adalah jenis minyak nabati. Oleh karena itu, penggunaan metode ini sangat ramah terhadap lingkungan karena belakangan ini penanggulangan masalah lingkungan sering dilakukan. Metode MQL dengan menggunakan minyak nabati ini memiliki beberapa keunggulan, diantaranya: ramah lingkungan, meningkatkan kualitas daur ulang chip, mengurangi biaya produksi dan mengurangi pemeliharaan mesin karena kontaminasi pendingin.

Metode MQL (Minimum Quantity Lubrication) memerlukan gas bertekanan. Proses pemesinan dengan menggunakan MQL memerlukan jumlah pelumas atau coolant lebih sedikit sehingga tidak banyak pelumas yang terbuang. Metode MQL dapat dikombinasikan dengan minyak nabati sehingga lebih ramah lingkungan (Desmas dkk, 2016). Minimum Quantity Lubrications (MQL) menghasilkan 
peningkatan yang signifikan pada umur dari alat potong yang digunakan yaitu sekitar 30\% dibandingakan dengan pemotongan kering (Chinchanikar dkk, 2015). Budi Basuki (2014) menyatakan bahwa, teknik tetesan menghasilkan kekasaran permukaan lebih rendah dibanding dengan proses dry dan wet. Terjadi penurunan kekasaran permukaan sebesar 37.8\% dibanding teknik dry dan 22.8\% dibanding teknik wet. Teknik tetesan menghasilkan kekasaran lebih tinggi 3.1\% dibanding teknik MQL. Namun demikian dalam artikel ini tidak membahas tentang perubahan tingkat kekasaran bahan yang diakibatkan oleh metode pemesinan yang dilakukan.

Alumunium adalah salah satu logam yang memiliki sifat resistensi yang baik terhadap korosi, hal ini dikarenakan fenomena pasivasi. Fenomena pasivasi adalah terbentuknya lapisan alumunium oksida ketika alumunium terpapar dengan udara bebas, lapisan oksida ini yang mencegah oksidasi lebih lanjut (Amanto dan Daryanto, 2006). Alumunium memiliki sifat tahan korosi yang baik dan memiliki berat yang lebih ringan daripada baja. Alumunium memiliki tingkat keuletan yang baik ketika suhu dingin. Jenis logam ini dipakai secara luas dalam bidang transportasi, kimia, listrik, bangunan dan alatalat penyimpanan (Tarmizi dan Prayoga, 2016). Paduan aluminium seng (Al-Zn) memiliki kekuatan tertinggi, aluminium dengan paduan seng sebesar $5,5 \%$ seng dapat memiliki kekuatan tensil sebesar 80Mpa dengan elongasi sebesar 11\% dalam setiap dalam setiap $50 \mathrm{~mm}$ bahan. Bandingkan dengan $\mathrm{Al}-\mathrm{Mg}$ dengan $1 \%$ magnesium memiliki kekuatan tensil $410 \mathrm{Mpa}$ namun memiliki elongasi sebesar $6 \%$ setiap 50 mm bahan.

Bobic, dkk (2009) menyatakan bahwa matriks logam berbasis aluminium dan seng dapat memberikan ketahanan yang baik untuk keausan geser dan abrasi. Pemilihan matriks logan dan fasa penguat pada umumnya didasarkan pada pencapaian sifat komposit yang diinginkan.
Pada dasarnya alumunium merupakan logam yang menghantarkan panas yang sangat baik. Oleh karena itu, ketika alumunium dikerjakan pada proses pemesinan akan mengakibatkan alumunium menjadi panas akibat terjadi gesekan antara alat potong dan benda kerja. Panas yang terjadi kemudian didinginkan secara mendadak oleh cairan pendingin yang disemprotkan. Pendinginan yang secara mendadak ini tentunya akan berpengaruh pada tingkat kekerasan bahan alumunium itu sendiri.

Gunawan Dwi Haryadi (2006) menyatakan bahwa kekerasan suatu bahan didefinisikan sebagai ketahanan suatu bahan terhadap penetrasi material lain pada permukaannya. Uji kekerasan lekukan adalah uji yang sering digunakan pada bahan logam. Jenis-jenis pengujian lekukan, diantaranya: Uji Kekerasan Rockwell, Uji Kekerasan Brinell, Uji Kekerasan Vickers dan Uji Tarik. Pengujian ini bertujuan untuk mengetahui nilai kekerassan dari suatu bahan yang sedang diteliti. Menurut I Ketut Suarsana (2017) kekerasan sering dinyatakan sebagai kemampuan untuk menahan indentasi/penetrasi/abrasi. Terdapat 3 jenis pengukuran kekerasan, tergantung cara melakukan pengujian, yaitu: (1) Kekerasan gores (Scratch Hardness), (2) Kekerasan lekukan (Indentation Hardness), (3) Kekerasan pantulan (Rebound). Pengujian kekerasan yang menarik yang berkaitan dengan bidang rekayasa untuk material logam adalah pengujian lekukan. Pengujian bahan jenis lekukan ini memiliki beberapa cara, antaralain: Pengujian Brinel, Pengujian Rockwell, Pengujian Vickers, Pengujian Microhardnets dan lain-lain.

Microhardnest test merupakan pengukuran kekerasan pada suatu bahan pada daerah yang sangat kecil, misalnya pada salah satu strukturmikro atau pada lapisan yang sangat tipis misalnya pada lapisan electroplating. Uji kekerasan mikro ini dapat menyediakan data yang diperlukan ketika diperlukan struktur mikro individu dalam matriks yang lebih besar, atau bisa juga saat menguji bahan seperti foil yang sangat tipis 
dan juga saat menentukan gradien kekerasan spesimen material. Pengujian ini dilakukan dengan gaya relatif kecil, yakni dibawah $1 \mathrm{~kg}$ menggunakan mesin yang dikombinasi dengan mikroskop. Cara ini dikenal dengan Mikro Vickers atau Knoop.

Pengukuran mikro Vickers dengan menggunakan indentor yang sama dengan uji Vickers dan perhitungan angka kekerasannya. Gaya tekan yang digunakan relatif kecil, yaitu antara 1-1000gr dengan panjang diagonal diukur dengan mikron. Gaya yang diberikan semakin kecil maka semakin tinggi finishing metallograpgic yang dibutuhkan. Hal-hal yang harus diperhatikan ketika melakukan pengijian kekerasan mikro, yaitu permukaan benda uji, dimensi material, data yang diinginkan dan ketersediaan alat uji.

Knoop Microhardness Test menggunakan indentor piramid intan dengan alasnya berbentuk belah ketupat dengan perbandingan diagonal 1:7. Permukaan benda yang akan diuji haruslah halus dan bebas kotoran. Pengukuran angka kekerasan Knoop dihitung dengan menggunakan rumus:

$$
H K=\frac{14.229 P}{l^{2}}
$$

Dimana:

$\mathrm{P}=$ gaya tekan $(\mathrm{g}) \quad \mathrm{l}=$ panjang diagonal tapak tekan yang terpanjang $(\mu)$

\section{METODE}

Metode penelitian yang digunakan adalah metode eksperimen. Sugiyono (2009) menjelaskan bahwa metode penelitian eksperimen adalah metode penelitian yang digunakan untuk mencari pengaruh perlakuan tertentu terhadap yang lain dalam kondisi yang terkendalikan. Penelitian dengan menggunakan metode eksperimen bertujuan untuk mengetahui pengaruh suatu perlakuan. Perlakuan (treatment) yang dimaksud adalah metode pemberian cairan pendingin, yaitu dengan menggunakan metode MQL dan wet machining.
Penelitian ini bertujuan untuk mengetahui pengaruh dari kedua metode tersebut pada tingkat kekerasan bahan alumunium yang dikerjakan dengan menggunakan mesin CNC 3A (Milling). Spesimen yang digunakan adalah paduan $\mathrm{Al}-\mathrm{Zn}$ dengan ukuran 100x30x20 mm sebagaimana ditunjukkan pada Gambar 1. Eksperimen dilakukan 3 kali pemakanan pada tiap metode yang digunakan, kemudian dilakukan pengujian distribusi kekerasan pada mesin micro vickers. Diagram alir penelitian sebagaimana ditunjukkan pada Gambar 2.

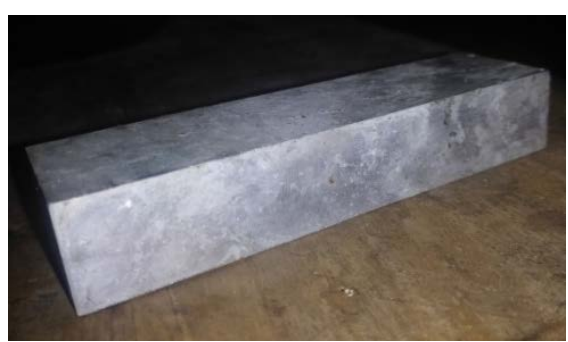

Gambar 1 Spesimen

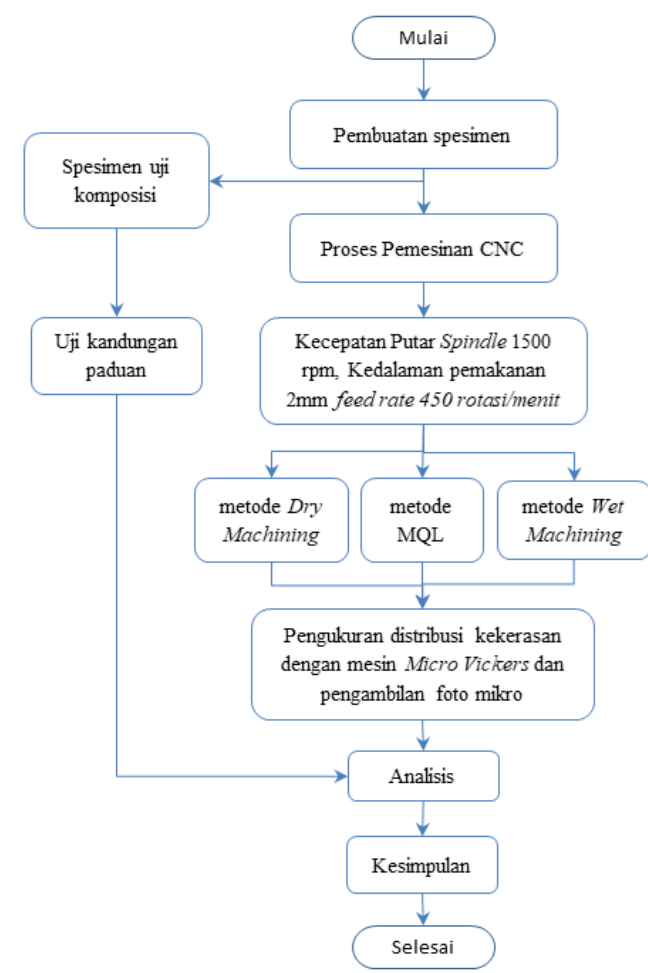

Gambar 2 Diagram Alir Penelitian

Uji distribusi kekerasan dilakukan pada bidang yang tidak diberikan proses pemesinan, karena yang akan diukur atau diteliti adalah perbedaan kekerasan yang terjadi pada 
spesimen uji tersebut. Pengujian dilakukan pada bidang lebar dan tinggi yaitu pada ukuran $20 \mathrm{x}$ 30mm. Pengukuran dilakukan 10 kali sepanjang $10 \mathrm{~mm}$. Hal ini ditujukan untuk melihat seberapa besar distribusi kekerasan yang terjadi pada tiap metode yang digunakan.

\section{HASIL DAN PEMBAHASAN}

Pengujian komposisi bertujuan untuk mengetahui unsur-unsur pembentuk suatu benda yang diuji. Pengujian ini berguna untuk menganalisis kekuatan mekanis yang dimiliki oleh benda uji. Hasil dari pengujian komposisi bahan sebagaimana ditunjukkan pada Tabel 1.

Tabel 1 Komposisi Benda Uji

\begin{tabular}{cc}
\hline Unsur & Kadar \% \\
\hline $\mathrm{Al}$ & 94,27 \\
$\mathrm{Si}$ & $<0,05$ \\
$\mathrm{Fe}$ & $<0,05$ \\
$\mathrm{Cu}$ & 0,254 \\
$\mathrm{Mn}$ & $<0,02$ \\
$\mathrm{Mg}$ & 0,348 \\
$\mathrm{Cr}$ & $<0,015$ \\
$\mathrm{Ni}$ & 1,05 \\
$\mathrm{Zn}$ & 3,49 \\
$\mathrm{Sn}$ & $<0,05$ \\
$\mathrm{Ti}$ & $<0,01$ \\
$\mathrm{~Pb}$ & $<0,03$ \\
$\mathrm{Be}$ & 0,0006 \\
$\mathrm{Ca}$ & 0,0028 \\
$\mathrm{Sr}$ & $<0,0005$ \\
$\mathrm{~V}$ & $* 0,377$ \\
$\mathrm{Zr}$ & $<0,003$ \\
\hline
\end{tabular}

Pengujian komposisi kimia dari benda uji dilakukan dengan menggunakan mesin Spectrometer Metal Scan dengan pembacaan secara otomatis memberikan hasil komposisi kimia. Standart pengujian ini menggunakan ASTM D7751-16. Komposisi diatas menunjukkan benda uji tersebut berjenis aluminium 7075. Distribusi kekerasan yang dimaksud adalah tingkat kekerasan pada tiap titik benda yang telah dikerjakan dengan mesin CNC Milling, dengan menggunakan tiga metode pendinginan yaitu dry machining, wet machining dan Minimum Quantity Lubrication. Uji kekerasan dilakukan dengan menggunakan mesin Micro Vickers. Hasil dari pengujian kekerasan dengan menggunakan mesin Micro Vickers sebagaimana ditunjukkan pada Tabel 2 dan 3.

Tabel 2 Distribusi Kekerasan pada Dry Machining

\begin{tabular}{cccccc}
\hline & & \multicolumn{4}{c}{ Distribusi Kekerasan Benda (HV) } \\
\cline { 3 - 6 } No & Jarak & 1 & 2 & 3 & $\begin{array}{c}\text { Rata- } \\
\text { rata }\end{array}$ \\
\hline 1 & $2 \mu \mathrm{m}$ & 219,93 & 220,37 & 219,6 & 219,87 \\
2 & $4 \mu \mathrm{m}$ & 216,53 & 212,13 & 213 & 213,89 \\
3 & $6 \mu \mathrm{m}$ & 211,27 & 208,3 & 210,87 & 210,11 \\
4 & $8 \mu \mathrm{m}$ & 207,97 & 205,67 & 207.43 & 207,02 \\
5 & $10 \mu \mathrm{m}$ & 204,37 & 202,5 & 204,87 & 203,91 \\
6 & $12 \mu \mathrm{m}$ & 199,2 & 196,8 & 199,47 & 198,49 \\
7 & $14 \mu \mathrm{m}$ & 193,4 & 193,4 & 193,03 & 193,28 \\
8 & $16 \mu \mathrm{m}$ & 188,57 & 188,1 & 188,17 & 188,28 \\
9 & $18 \mu \mathrm{m}$ & 181,93 & 182 & 182,6 & 182,18 \\
10 & $20 \mu \mathrm{m}$ & 178,5 & 179,83 & 178,87 & 179,07 \\
\hline
\end{tabular}

Tabel 2 menunjukan tingkat kekerasan yang diambil pada setiap titik yang diambil secara vertikal. Tabel tersebut menunjukan adanya perbedaan tingkat kekerasan pada setiap titik yang telah diberikan perlakuan pemesinan yaitu dengan melakukan pemakanan dengan mesin CNC Milling tanpa menggunakan coolant sama sekali. Metode ini memberikan peningkatan kekerasan yang sangat signifikan, dapat dilihat dari perbedaan kekerasan yang terjadi pada tiap titik yang diambil

Tabel 3 Distribusi Kekerasan pada Wet Machining

\begin{tabular}{cccccc}
\hline & \multicolumn{4}{c}{ Distribusi Kekerasan Benda (HV) } \\
No & Jarak & 1 & 2 & 3 & $\begin{array}{c}\text { Rata- } \\
\text { rata }\end{array}$ \\
\hline 1 & $2 \mu \mathrm{m}$ & 198,93 & 198,87 & 198,43 & 198,74 \\
2 & $4 \mu \mathrm{m}$ & 184,87 & 185,53 & 185,27 & 185,22 \\
3 & $6 \mu \mathrm{m}$ & 179,47 & 176,87 & 175,87 & 177,4 \\
4 & $8 \mu \mathrm{m}$ & 170,5 & 171,27 & 170,63 & 170,8 \\
5 & $10 \mu \mathrm{m}$ & 168,7 & 167,97 & 168,57 & 168,41 \\
6 & $12 \mu \mathrm{m}$ & 166,7 & 166,47 & 165,2 & 166,12 \\
7 & $14 \mu \mathrm{m}$ & 165,9 & 164,07 & 164,13 & 164,7 \\
8 & $16 \mu \mathrm{m}$ & 162,57 & 161,87 & 161,37 & 161,94 \\
9 & $18 \mu \mathrm{m}$ & 160,87 & 160 & 159,23 & 160,03 \\
10 & $20 \mu \mathrm{m}$ & 159,23 & 157,67 & 157,9 & 158,26 \\
\hline
\end{tabular}


Tabel 3 menjelaskan distribusi kekerasan yang terjadi pada tiap titik spesimen yang telah diberikan perlakuan berupa pemakanan dengan menggunakan mesin CNC Milling dengan menggunakan coolant. Pengambilan data distribusi kekerasan pada spesimen tersebut diambil secara vertikal dengan jarak yang telah ditentukan. Penggunaan coolant pada proses pemesinannya inilah yang menyebabkan metode ini disebut dengan metode basah/ Wet machining, karena benda kerja yang dihasilkan dibasahi oleh coolant. Tidak terjadi peningkatan kekerasan benda yang signifikan, hal ini dikarenakan coolant bekerja dengan baik.

Tabel 3 Distribusi Kekerasan pada $M Q L$

\begin{tabular}{|c|c|c|c|c|c|}
\hline \multirow[b]{2}{*}{ No } & \multirow[b]{2}{*}{ Jarak } & \multicolumn{4}{|c|}{ Distribusi Kekerasan Benda (HV) } \\
\hline & & 1 & 2 & 3 & $\begin{array}{c}\text { Rata- } \\
\text { rata }\end{array}$ \\
\hline 1 & $2 \mu \mathrm{m}$ & 203,6 & 204,87 & 204,47 & 204,31 \\
\hline 2 & $4 \mu \mathrm{m}$ & 200,03 & 196,4 & 196,4 & 197,61 \\
\hline 3 & $6 \mu \mathrm{m}$ & 194,03 & 192,83 & 192,13 & 192,99 \\
\hline 4 & $8 \mu \mathrm{m}$ & 186,53 & 186,13 & 184,6 & 185,75 \\
\hline 5 & $10 \mu \mathrm{m}$ & 182,57 & 182,53 & 181,13 & 182,08 \\
\hline 6 & $12 \mu \mathrm{m}$ & 179,37 & 178,2 & 176,3 & 177,96 \\
\hline 7 & $14 \mu \mathrm{m}$ & 176,43 & 174,8 & 173,73 & 174,99 \\
\hline 8 & $16 \mu \mathrm{m}$ & 171,17 & 172,17 & 168,67 & 170,67 \\
\hline 9 & $18 \mu \mathrm{m}$ & 167,03 & 167,03 & 164,8 & 166,29 \\
\hline 10 & $20 \mu \mathrm{m}$ & 162,8 & 161,97 & 161,07 & 161,95 \\
\hline
\end{tabular}

Tabel 4 menunjukkan data distribusi kekerasan dengan menggunakan metode MQL. Metode ini menggunakan campuran dari coolant dan dengan menggunakan udara bertekanan tinggi. Metode ini digunakan untuk mengurangi penggunaan coolant tetapi tidak mengurangi kualitas dari benda yang dikerjakan. Hasil yang diperoleh adalah peningkatan kekerasan yang tidak terlalu signifikan, hal ini menujukkan bahwa penggunaan coolant yang minimum dapat mengurangi tingkat kekeraan yang dapat terjadi pada benda yang telah dikerjakan.

Gambar 3 menunjukkan bahwa nilai kekerasan variabel kontrol dry machining (garis merah) memiliki nilai kekerasan yang lebih tinggi dari yang lain. Nilai kekerasan MQL (garis hijau) nilai kekerasannya berada di atas metode wet machining (garis biru). Hal ini menunjukkan bahwa, nilai kekerasan $d r y$ machining lebih tinggi daripada nilai kekerasan 2 metode yang lain.

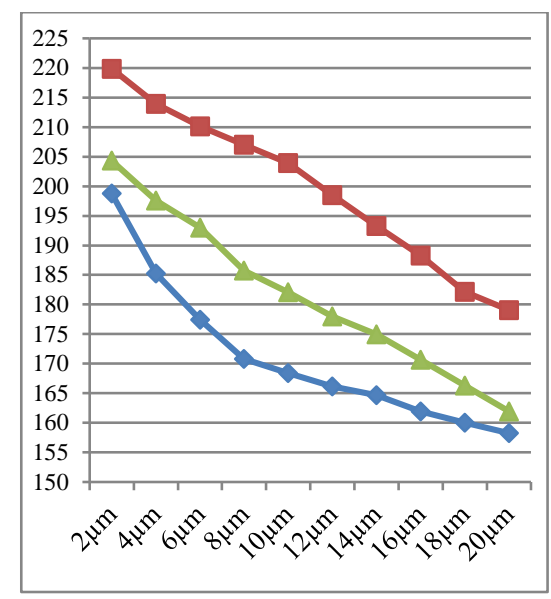

Gambar 3 Distribusi Kekerasan

Gambar 3 juga menjelaskan tentang perbedaan tingkat kekerasan pada tiap metode yang dilakukan. Metode dry machining menghasilkan tingkat kekerasan yang paling tinggi. Pada metode wet machining dan MQL ada perbedaan yang terjadi pada tingkat kekerasan benda dengan metode MQL lebih tinggi dibandingkan dengan metode wet machining. Barglik (2018), menjelaskan bahwa ada beberapa parameter yang mempengaruhi distribusi kekerasan yang benar seperti: suhu pengerasan, laju pemanasan dan pendinginan, sifat material dan ketergantungannya terhadap suhu, parameter perpindahan panas, dan lainlain.

Pada proses pemesinan setidaknya ada tiga hal yang dapat diamati terkait dengan tingkat kekerasan benda kerja, yaitu gesekan antara benda kerja dengan alat potong, panas yang ditimbulkan dan gram yang dihasilkan

(a) Gesekan benda dan alat potong. Hal ini terjadi ketika alat potong menyayat benda, besarnya gesekan dipengaruhi oleh luasan permukaan benda. Benda yang dipotong/disayat akan menghasilkan geram, geram ini lah yang menyebabkan gaya gesek yang terjadi sangat tinggi jika tidak disingkirkan. Oleh karena itu, digunakan udara maupun cairan coolant untuk 
membuang sisa-sisa geram pada permukaan benda kerja. Fortunato dkk (2015) menyatakan bahwa sumber panas akan terbentuk dan terletak pada bidang antarmuka gesek. Tidak hanya pada bidang antarmuka tetapi juga agak menusuk ke dalam. data hasil eksperimen menunjukkan bahwa metode dry machining memiliki tingkat kekerasan yang paling tinggi. Hal ini menunjukkan bahwa dengan metode dry machining gaya gesek yang terjadi sangat tinggi sehingga dapat mempengaruhi distribusi kekerasannya.

(b) Panas yang ditimbulkan. Selanjutnya terkait dengan panas yang dihasilkan pada proses pemesinan, panas dipengaruhi dari gesekan antara alat potong dengan benda kerja yang kemudian diberikan media pendingin. Pada metode wet machining dan MQL yang menggunakan media pendingin memiliki penyerapan yang lebih lambat dibandingkan metode dry machining. Panas yang terjadi terhalang media pendingin (coolant) sehingga tidak berpengaruh banyak pada tingkat distribusi kekerasan benda, berbeda halnya dengan metode dry machining panas yang diserap banyak dan berakibat pada meningkatnya tingkat kekerasan logam tersebut. Facasso (2010) menjelaskan bahwa tujuan dari adanya perlakuan panas berbedabeda: peningkatan kekuatan, peningkatan kekerasan, menurunkan tingkat stres, meningkatkan daktilitas dan lan sebagainya. Dari pernyataan tersebut dapat ditarik kesimpulan bahwa panas yang terjadi pada suatu bahan dapat meningkatkan tingkat kekerasan bahan tersebut.

(c) Gram yang dihasilkan. Perbedaan yang terjadi antara geram hasil sayatan metode dry machining, wet machining, dan MQL adalah hasil sayatannya. Pada metode dry machining sayatan geram warnanya menjadi gelap, metode MQL geram yang dihasilkan warnanya tidak segelap metode dry machining, dan metode wet machining geram yang dihasilkan terlihat sangat mengkilap. Hal ini dikarenakan, pada proses dry machining banyak geram-geram yang sangat halus yang menyangkut pada ujung alat potongnya, sehingga geram yang halus tadi ikut bergesekan dengan permukaan bidang potong dan mengakibatkan gaya gesek yang sangat besar. Metode MQL dapat menyemburkan geram dengan angin yang bertegangan tinggi, akan tetapi masih ada geram yang menempel pada permukaan alat potong (end mill) sehingga masih ada bekas sayatan kecil pada permukaan geram. Sedangkan metode wet machining dengan membanjiri permukaan benda dan permukaan alat potong (end mill) dengan cairan pendingin mengakibatkan geram yang sangat halus tadi terbawa oleh aliran cairan pendingin keluar dari bidang kerja dan membuat alat potong tetap bersih dari geram yang menempel. Hasil potongan geram dari ketiga metode tersebut ditunjukkan pada Gambar 4.

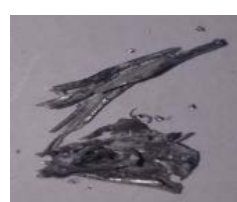

(a)

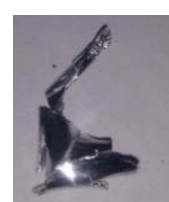

(b)

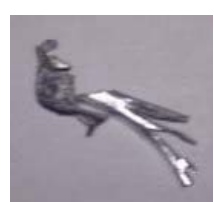

(c)
Gambar 4 Geram/Chip Hasil Potongan Metode: (a) dry machining, (b) wet machining dan (c) MQL

Pada proses pemotongan hampir seluruh energi diubah menjadi panas melalui proses gesekan antara geram dengan pahat dan antara pahat dengan benda kerja, serta perusakan molekuler atau ikatan atom pada bidang geser (shear plane). Panas tersebut akan membuat geram berwarna lebih gelap (gosong) sehingga penggunaan metode wet machining lebih efektif karena penyerapan panas dari proses pemesinan diserap oleh coolant. Sedangkan metode dry machining panas yang terjadi sangatlah tinggi dan tidak ada cairan pendingin sebagai penyerap panas, dan akhirnya membuat geram hasil pemesinan menjadi berwarna lebih gelap dari metode yang lainnya.

Semakin ke bawah tingkat kekerasan benda antara metode dry machining, MQL, dan wet machining semakin mendekati tingkat kekerasan dari raw material-nya. Distribusi kekerasan dari permukaan ke inti akan semakin 
rendah tingkat kekerasannya. Penurunan tingkat kekerasan tergantung metode yang digunakan, metode dry machining akan lebih dalam penembusannya dibandingkan dengan metode MQL dan wet machining. Metode wet machinning dan MQL dapat menghentikan distribusi panas yang terjadi dengan menyerapkan panas tersebut pada coolant, baik secara dibanjirkan maupun disemprotkan dengan tekanan tinggi. akan tetapi, hasil dari metode MQL dan wet machining memiliki perbedaan yaitu dari tingkat kekerasan di tiap titiknya. Hal tersebut mengindikasikan bahwa penggunaan metode wet machining lebih efektif dalam hal penyerapan panas yang dihasilkan dari gesekan benda dan alat potong.

Semakin dekat suatu titik terhadap permukaan pemakanan akan berdampak pada tingginya tingkat kekerasan suatu benda. Tingkat kekerasan suatu benda dipengaruhi oleh panas yang dihasilkan oleh benda itu sendiri baik melalui gesekan dengan alat potong maupun yang lainnya. Proses pemberian coolant juga memberi pengaruh terhadap tingkat kekerasan benda tersebut. Pemberian coolant secara dibanjiri mengakibatkan distribusi kekerasan suatu benda tidak berubah secara signifikan dan penembusan panasnya sangat dangkal yang berakibat pada dangkalnya wilayah yang terdampak proses machining. Distribusi kekerasan yang dangkal mengakibatkan wilayah yang mengalami kenaikan tingkat kekerasan pun semakin dangkal pula.

Tingkat kekasaran juga dapat diamati dari struktur mikro yang diperoleh dari masingmasing permukaan hasil penggunaan metode pendinginan yang berbeda. Adapun perbedaan dari struktur mikro yang diambil dari setiap benda ditunjukkan pada Gambar 5.

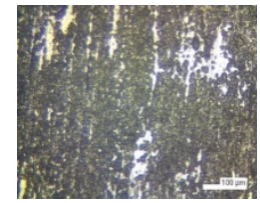

(a)

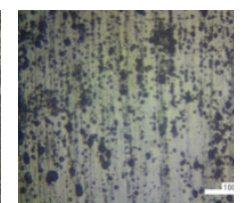

(b)

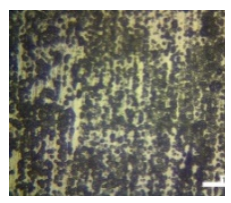

(c)
Gambar 5 Struktur Mikro dari Metode: (a) Dry Machining, (b) Wet Machining, dan (c) MQL
Gambar 5(a) menunjukkan bahwa struktur mikro pada spesimen dengan menggunakan metode dry machining memiliki susunan $\mathrm{Al}-\mathrm{Zn}$ yang sangat rapat. Hal ini dikarenakan laju pendinginan pada spesimen yang diberikan perlakuan pemesinan dengan metode dry machining berjalan sangat lambat.Sedangkan struktur mikro yang terbentuk pada spesimen yang telah mendapat perlakuan pemesinan dengan metode wet machining (Gambar 5.b) memiliki susunan $\mathrm{Al}$ dan Zn yang renggang. Hal ini dikarenakan, laju pendinginan pada spesimen dengan metode wet machining memiliki laju pendinginan yang sangat cepat.

Struktur mikro yang terbentuk dari metode Minimum Quantity Lubrication (MQL) terlihat sudah mulai merapat (Gambar 5.c). Hal ini dikarenakan laju pendinginan pada spesimen ini tidak terlalu cepat dan tidak juga terlalu lambat yang mengakibatkan ikatan struktur $\mathrm{Al}$ dan Zn sudah mulai merapat.

Rapatnya fase Al-Zn pada metode dry machining meningkatkan nilai kekerasan pada spesimen yang dikerjakan. Hal ini dikarenakan, Zn meningkatkan nilai kekerasan pada logam tersebut. Maka dari itu, distribusi kekerasan logam paduan Al-Zn dengan metode dry machining lebih tinggi daripada metode wet machining dan MQL. Metode wet machining memiliki tingkat laju pendinginan lebih cepat dari pada metode MQL, hal ini dapat terlihat dari fasa Al-Zn pada struktur mikro kedua metode tersebut.

\section{SIMPULAN}

Perbedaan distribusi kekerasan yang terjadi antara metode MQL dan metode wet machining terletak pada tingkat kekerasan yang terjadi diantara dua metode tersebut. Grafik distribusi yang terjadi pun hampir sama akan tetapi metode MQL grafik kekerasan yang dihasilkan lebih tinggi dari metode wet machining. Hal ini bisa terjadi dikarenakan panas yang diserap oleh coolant tidak terserap 
sepurna sehingga tingkat kekerasan pada spesimen yang menggunakan metode MQL memiliki nilai yang lebih tinggi dibandingkan nilai kekerasan dengan metode wet machining. Panas yang diserap ini juga berdampak pada struktur mikro yang dihasilkan. Struktur mikro yang dihasilkan dari metode MQL lebih rapat daripada metode wet machining karena perbedaan panas yang diserap spesimen dengan menggunakan metode yang berbeda ini. Struktur mikro spesimen menunjukkan bahwa dengan menggunakan metode dry machining memiliki fasa Al-Zn yang lebih rapat daripada metode wet machining dan MQL. Metode wet machining memiliki tingkat pendinginan yang paling baik karena memiliki fase $\mathrm{Al}-\mathrm{Zn}$ yang lebih renggang daripada metode MQL.

\section{DAFTAR RUJUKAN}

Amanto dan Daryanto. (2006). Ilmu Bahan. Jakarta: Bumi Aksara

Barglik, Jerzy. (2018). Identification of Temperature and Hardness Distribution During Dual Frequenzy Induction Hardening of Gear Wheels. Journal Archives of Electrical Enggineering 67(4): 913-923.

Budi Basuki. (2014). Pengaruh Metode Minimum Lubrication Keausan Pahat dan Kekasaran Permukaan Benda AISI 4340. Jurnal Teknologi 7(2), 112-117.

Bobic, B., dkk. (2009). Corrosion of Aluminium and Zimc-Alluminium Alloys Based Metal-Matrics Composites.
Journal of Tribilogy in Industry 31: 4453.

Desmas Arifianto Patriawan, dkk. (2016). Studi Pendahuluan Penggunaan Minimum Quantity Lubricant pada Proses Pemesinan. Makalah Disajikan pada Seminar Nasional Sains dan Teknologi Terapan IV Institut Teknologi Adhi Tama. Surabaya. 153-160.

Fortunato, G., dkk. (2015). General Theory of Frictional Heating With Aplication to Rubber Friction. Journal of Phisyc: Condens ed Matter

Gunawan Dwi Haryadi. (2006). Pengaruh Suhu Tempering Terhadap Kekerasan, Kekuatan Tarik, dan Struktur Mikro pada Baja K-460. Journal Rotasi

I Ketut Suarsana,. (2017). Ilmu Material Teknik. Denpasar: Universitas Udayana.

Klockle. (2011). Manufacturing Proses. Berlin: Springger.

Chinchanikar, S., Kulkarni, A.P., Choudhury, S.K. (2015). Hard Turning Under Dry and Minimum Quantity Lubrication (MQL): Comparative Asessment Through Multy-Objective Optimization. Journal of Production Engineering 18 (2): 16-20.

Sugiyono. 2009. Metode Penelitian Kuantitatif, Kualitatif dan R\&D. Bandung: Alfabeta

Tarmizi Tjikmat Abdullah dan Boy Prayoga. (2016). Analisa Sifat Mekanik dan Struktur Mikro pada Proses Friction Welding Stir Aluminium 5052. Journal of Industrial Research 10(2), 70-82. 